\title{
建筑工程施工进度管理的重要性
}

\author{
施剑 麻小娟 \\ 浙江富泰建设有限公司 \\ DOI:10.18686/bd.v1i12.1156
}

[摘要] 由于建筑工程涉及范围广,所需要管理的内容多, 而面对众多的管理内容, 就会使建筑企业忽略对建筑工程的进度 管理工作, 导致建筑工程施工进度被延长。因此, 建筑工程需要加强进度管理工作, 本文就对进度管理在建筑工程管理中的重 要性进行阐述,并提出做好进度管理工作的对策, 以期为建筑工程管理工作提供参考依据。

[关键词] 进度管理;建筑工程管理; 重要性

随着我国社会经济的快速发展, 人们生活质量不断提 高,对建筑物的需求量逐渐增加, 在此种情况下, 各种各样的 建筑工程应运而生, 使得建筑行业成为我国国民经济的重 要组成部分。但是建筑工程在施工过程中进度管理工作还 存在一些问题,对建筑企业的发展产生一定的负面影响。基 于此, 本文就对建筑工程管理中的进度管理工作进行探究, 以期推动建筑企业实现快速发展。

\section{1 建筑工程管理中进度管理工作的重要性分析}

在我国建筑行业快速发展的背景下, 使得建筑工程数 量增多、规模变大、管理内容呈现出多样化趋势,包含着建 筑项目工程施工计划、施工材料、施工进度管理等方方面面 内容,但是在这众多管理内容中, 进度管理最为重要,不仅关 系到建筑工程施工质量, 还关系到建筑工程施工成本和建 筑企业的经济效益,因此,相关人员需要做好建筑工程管理 中的进度管理工作, 从而推动建筑工程实现快速发展。通常 情况下, 建筑工程管理中进度管理工作的重要性主要包含 以下几个方面内容: 第一,建筑工程在开工前期,企业双方在 合同中对建筑施工工期有了明确的要求, 要求施工单位需 要在规定的时间内完工, 所以对建筑工程进行进度管理可 以将施工中遇到的突发事件进行及时调整, 进而保证建筑 工程如期完工。第二,由于我国建筑工程具有复杂性特点,各 个方面都需要花费大量资金,施工成本高,一旦工期延长,就 会增加不必要的人力、财力等投人, 在此种情况下, 就会导致 建筑工程成本上升, 而对建筑工程施工进度进行管理, 可以 保证保证施工人员施工质量, 降低工程施工中出现差错的 几率,对所花费的资金进行控制,保证工程资金使用合理,实 现建筑工程成本控制工作。第三,建筑工程工期长,在施工过 程中经常会经历多个季节,造成工程出现变更情况,影响建 筑工程工期。在此种情况下, 相关人员对建筑工程施工进度 进行管理可以保证建筑工程如期完工, 进而帮助施工单位 营造一个良好的形象, 吸引更多建筑企业与其进行合作,从 而为施工单位获取更多的项目, 提升施工单位的经济效益。 第四, 相关人员在建筑工程管理中实施进度管理工作可以 保证建筑工程规模, 相关人员根据建筑工程项目具体情况 制定科学合理的进度管理方法, 对建筑工程项目施工进度
进行控制,进而保证建筑工程项目施工质量, 推动我国建筑 行业实现快速发展。

\section{2 进度管理在建筑工程管理中应用的对策分析}

2.1 建筑工程施工进度管理方法分析

由于建筑工程具有复杂性, 在施工中经常会遇到各种 各样的问题,影响建筑工程的施工进度, 导致建筑工程无法 及时交工。在此种情况下,相关人员就需要选择合适的施工 进度管理方法,对建筑工程施工进度进行管理,具体可以从 以下几个方面展开:第一,相关人员需要根据工程合同规定, 对建筑工程施工中将要面临的问题进行分析, 然后根据分 析结果制定针对性的进度管理方法, 保证工程施工进度。第 二, 当工程进度管理方案制定完毕后, 相关人员需要将进度 管理方案上交给上级领导, 让上级领导进行审核, 审核合格 后,才可以进行使用。第三,建筑企业相关人员需要在工程施 工前,与施工方做好技术交底工作, 并提前对施工人员进行 培训,让其在施工过程中采用先进的施工设备、施工技术,进 而保证建筑工程施工进度。第四, 在建筑工程施工过程中,相 关人员需要对工程施工中所产生的数据信息进行收集,然 后对数据信息进行仔细分析, 找出数据中存在不合理的地 方,然后制定针对性的解决对策,对问题进行解决,从而保证 建筑工程施工进度, 提高建筑工程施工质量。第五, 当建筑工 程遇到变更情况时,施工单位需要根据工程具体情况, 对工 程施工中所使用的材料、设备等方面内容进行统计, 然后根 据工程后续施工内容, 对建筑工程施工材料、施工人员、施 工进度等方面内容重新编制,调整施工时间,进而保证建筑 工程能够如约完成。

\section{2 建筑工程进度管理的主要途径分析}

由于建筑工程工期长, 施工单位在施工中经常会将工 期进行分割,然后分阶段进行管理,进而保证建筑工程施工 进度。通常情况下, 建筑工程进度管理的主要途径包含以下 几个方面: 第一,施工单位在施工前期需要对建筑工程施工 路线进行合理规划, 对建筑工程项目变更等问题进行考虑, 制定相应的奖罚制度,对施工单位进行约束,进而保证建筑 项目施工进度,提高管理工作质量。第二,建筑工程在施工过 程中经常会遇到一些不可抗因素,在此种情况下,可以在管 
理工作中融人信息化设备, 依靠计算机设备对建筑施工进 度进行提前编制, 并对建筑工程施工现场进行二十四小时 监督, 了解现场施工情况,及时发现施工中存在的问题, 然后 进行解决, 保证建筑工程施工进度。第三, 施工单位需要在施 工前对建筑工程施工工序进行查看, 对施工中每一阶段进 行的时间进行合理安排, 根据建筑工程项目施工具体情况, 对施工进度管理方案进行调整, 提高建筑工程施工进度管 理质量。第四, 由于部分建筑工程规模大, 在施工中所涉及到 的生产要素多, 在此种情况下, 施工单位就需要对生产要素进 行管理,保证施工中所使用的资源种类、数量都合理,提高建 筑工程进度管理工作质量。

\section{3 建筑工程施工进度管理的对策分析}

通常情况下, 建筑工程施工进度管理的对策主要包含 以下几个方面: 第一,建筑企业需要对施工进度管理工作予 以重视, 对工程项目管理模式和组织架构进行完善, 建立以领 导为主的工期控制小组, 选择管理能力强、具有组织协调意 识的工作人员担任工程工期管理负责人, 对建筑工程项目 施工进度合理控制。第二,建筑企业需要在施工前期对建筑 工程施工中所涉及的人力、财力、物力等方面内容进行合 理安排, 对格按照施工进度管理要求进行管理匀料进而保证 建筑工程施每一工作人员的工作内容进行明确,结合具体的 施工原则,建立完善的目标责任制,将管理工作落实到每一位 工作人员身上,进而调动施工人员工作积极性, 保证建筑工程 工期控制工作效率。第三, 建筑企业需要在施工合同中, 对施 工期限进行合理制定, 对施工期限延长的情况制定专门的 惩罚制度, 并专门制定一个应急预案, 将恶劣天气等因素造成 施工工期延长的情况针对性的应急方案, 进而保证建筑项 目施工进度。第四, 建筑企业需要对现有的进度管理人员进 行培训工作,提升管理人员的施工进度管理技术、业务素质 能力, 让其在管理过程中可以做到认真负责, 能够严格按照施
工进度管理要求进行管理,进而保证建筑工程施工进度合 理。第五,建筑企业可以采用动态管理方法对工程进度进 行管理,在管理工作中融入信息化设备,依靠计算机设备 对施工现场进行监督管理, 然后设置专门的管理人员对工 程进度进行跟踪调查, 对工程施工中遇到的问题及时解 决, 保证建筑项目各个施工环节作业进度, 进而提高建筑 工程整体的施工进度, 保证施工单位能够按期交工。

\section{3 总结语}

总而言之, 做好进度管理工作是建筑工程管理的重点 内容, 对建筑行业的快速发展起到至关重要的作用。因此建 筑企业就需要根据建筑工程的具体特点, 对每一施工环节 所需要花费的时间准确制定, 做好工程整体的进度规划, 并 对建筑工程施工中所需要使用的设备、施工材料、资金都充 分管理,进而保证建筑工程可以在规定的时间内完成,提高 建筑企业在市场上的核心竞争力, 推动建筑企业实现可持 续发展。

\section{参考文献:}

[1]刘伯能.探讨进度管理在建筑工程管理中的重要性 [J].城市建筑,2014,(2):115.

[2]马其祥.进度管理在建筑工程管理中的重要性分析 [J].房地产导刊,2017,(23):114.

[3] 黄柽炜。论进度管理在建筑工程管理中的重要性 [J].江西建材,2014,(8):298.

[4] 刘爽。进度管理在建筑工程管理中的重要性分析 [J].赤子,2015,(5):167.

[5]王寓. 关于加强建筑工程管理中进度管理的分析 [J].黑龙江科技信息,2015,(26):220.

[6]郭军.进度管理在建筑工程管理中的应用分析 [J]. 城市建筑,2014,(33):112. 